\title{
Article
}

\author{
Doi 10.5943/sif/1/1/10
}

Copyright $\odot$ Mushroom Research Foundation 2016

\section{Antimicrobial and cytotoxic activities of endophytic fungus Colletotrichum gloeosporioides isolated from endemic tree Cinnamomum malabatrum}

\author{
Packiaraj $\mathbf{R}^{1}$, Jeyakumar $\mathbf{S}^{1}$, Ayyappan $\mathbf{N}^{2}$, Adhirajan $\mathbf{N}^{3}$, Premkumar $\mathbf{G}^{\mathbf{1}}$, \\ Rajarathinam $\mathbf{K}^{1}$ and Muthuramkumar $\mathbf{S}^{1 *}$
}

${ }^{1}$ Department of Botany, Virudhunagar Hindu Nadar Senthikumara Nadar College (Autonomous), Virudhunagar - 626 001, Tamil Nadu, India.

${ }^{2}$ Department of Ecology, French Institute of Pondicherry, Puducherry- 605001.

${ }^{3}$ Department of Pharmaceutical Biotechnology/ Pharmacognosy, KMCH College of Pharmacy, Coimbatore - 641 048,

Tamil Nadu, India.

Packiaraj R, Jeyakumar S, Ayyappan N, Adhirajan N, Premkumar G, Rajarathinam K, Muthuramkumar S 2016 - Antimicrobial and cytotoxic activities of endophytic fungus Colletotrichum gloeosporioides isolated from endemic tree Cinnamomum malabatrum. Studies in Fungi 1(1), 104-113, Doi 10.5943/sif/1/1/10

\begin{abstract}
In a survey of endophytic fungi associated with endemic plant Cinnamomum malabatrum leaves harbored a bioactive endophytic isolate CMS 3 was identified as Colletotrichum gloeosporioides through morphological and phylogenetic analysis based on ITS-rDNA. The ethyl acetate extract of fermentation broth of Colletotrichum gloeosporioides CMS 3 displayed antimicrobial activity against gram positive and gram negative bacteria as well as the fungal pathogen, Candida albicans. The ethyl acetate crude extract showed in vitro cytotoxicity against the HeLa, MCF-7 and MG63 cancer cell lines with the $\mathrm{IC}_{50}$ values of $94.2 \mu \mathrm{g} / \mathrm{ml}, 84.3 \mu \mathrm{g} / \mathrm{ml}$ and $162 \mu \mathrm{g} / \mathrm{ml}$ respectively. Gas chromatography and Mass Spectrophotometry (GC-MS) analysis of crude extract confirmed that CMS 3 was a prolific producer of secondary metabolites, in which nearly $74 \%$ of the metabolites not listed in the NIST database. Major compounds were phenol 3, 5dimethoxy acetate (11.82 \%), 4'-isopropylidene-bis-(2-cyclohexyl) phenol, NDidehydrohexacarboxyl-2, 4, 5-trimethylpiperazine and 1, 2, 4-Triazolium ylide. These metabolites may be responsible for its antimicrobial and cytotoxic activities.
\end{abstract}

Key words - Antimicrobial potential - Colletotrichum gloeosporioides - Cytotoxic activity, Endemic tree - Endophytic fungus - GC-MS

\section{Introduction}

Globally, there is an ascending trend in life threatening diseases and emergence of drug resistant- bacterial pathogens which has become a serious health concern (WHO 2008). Therefore, there is an urgent need to search for newer and effective novel compounds from various biota. One such unexplored treasure trove is endophytic fungi, which reside in the internal tissues of plants, without causing apparent disease symptom (Tan \& Zou 2001). Plant endophytic fungi have the ability to produce array of bioactive compounds such as antibiotics, antiviral compounds, 
anticancer agents, antioxidants, antidiabetic agents, immunosuppressive compounds and biocontrol agents (Strobel et al. 2004, Kusari et al. 2014). Hence, there is a significant interest in screening of endophytic fungi for the discovery of novel metabolites to treat life threatening diseases. Areas with high endemicity possess specific endophytes that may have evolved with endemic plant species and could be a source of novel molecules heralding drug discovery (Strobel 2002).

In India, the Western Ghats is one of the most important hotspots of biodiversity and endemism, which harbors $\sim 45 \%$ of endemic plants (Myers et al. 2012). In this paper, we present the endophytic fungi associated with endemic tree Cinnamomum malabatrum (Lauraceae) and its bioactivities. Cinnamomum species are widely used in herbal therapy in treating colds, sinusitis, bronchitis and fungal infection (Kharwar et al. 2012). It also possesses diverse pharmacological effects such as anti-inflammatory (Annegowda et al. 2012), hepatoprotective (Maridass 2009), antioxidant (Harikumar et al. 2010), anticancer (Agarwal et al. 2013). Endophytes from species of Cinnamomum have been studied elsewhere (Strobel et al. 2001, Suwannarach et al. 2010, Santiago et al. 2012). However, there is no study to date on fungal endophytes and their bioactivities from endemic tree Cinnamomum malabatrum.

\section{Materials \& Methods}

\section{Sample collection, fungal isolation and purification}

Cinnamomum malabatrum leaves were collected during September 2013 from Uppangala village in the central Western Ghats of the Karnataka state, India $\left(12^{\circ} 32^{\prime} \mathrm{N}\right.$ latitude and $\left.75^{\circ} 39^{\prime} \mathrm{E}\right)$ and stored in sterile plastic bag and transported to lab in a igloo icy box within 48 hours. The identification of plant species was done at French Institute of Pondicherry, Puducherry.

During the process of endophytic fungal isolation, healthy leaf samples were thoroughly washed in running tap water, then surface sterilized by submerging them in $70 \%$ ethanol for 2 minutes, followed by $5 \%$ sodium hypochlorite $(\mathrm{NaOCl})$ solution for $5 \mathrm{~min}, 70 \%$ ethanol for 30 seconds and washed with sterile distilled water. Leaves were cut into $1 \mathrm{~cm}$ segments and placed on the Petri dish with potato dextrose agar (PDA) amended with streptomycin $(250 \mathrm{mg} / \mathrm{L})$ to avert bacterial growth and incubated at $30^{\circ} \mathrm{C}$ till the fungal mycelia started growing on the samples. Hyphal tips emerging out from the leaf segments were picked and grown on potato dextrose agar in pure culture and periodically checked for purity. Each pure isolate was stored on PDA slants at room temperature for further investigations.

\section{Identification of endophytic fungus}

Endophytic fungi were preliminarily grouped into genus or species level based on their microscopic characteristics (Ellis 1971, Muthumary 2013). Potential bioactive endophytic fungal strain was subjected to molecular identification amplifying by ITS-rDNA sequence based on preliminarily antimicrobial activity. Fungal genomic DNA was extracted using fungal DNA kit (InstaGene TM Matrix). Primers ITS1 (5'-TCCGTAGGTGAACCTGCGG-3' and ITS4 (5'TCCTCCGCTTATTGATATGC-3') were used for amplification of ITS-rDNA sequence. The PCR products were purified, sequenced and the sequence data were analyzed using BLAST software (BLASTN) at NCBI and submitted to Genbank (accession no. KT795465). The sequence obtained and some from known species were used to construct a neighbor-joining (NJ) phylogenetic tree by using MEGA 6.0 (Tamura et al. 2013) for identification of endophytic fungus.

\section{Fermentation and metabolite extraction}

Endophytic fungus was cultured in Potato dextrose broth at room temperature for 21 days under stationary conditions. Fermentation broth was separated from mycelium by filtration. The culture filtrate was extracted thrice with ethyl acetate (EtOAc). The ethyl acetate fraction was evaporated to dryness under reduced pressure at $45-55^{\circ} \mathrm{C}$ using rotary evaporator to obtain a crude extract. The concentrated crude extract was tested for the bioactivities. 


\section{Antimicrobial activity}

Antimicrobial activity of crude extracts was evaluated by means of agar-well diffusion assay (Basha et al. 2012) with some modifications. At various concentrations, the crude extract of fungi was tested against Staphylococcus aureus, Bacillus subtilis, Streptococcus faecalis (Gram positive bacteria), Escherichia coli, Salmonella typhimurium, Shigella boydii (Gram negative bacteria) on Muller-Hinton agar medium. The antifungal activity was tested against Candida albicans using potato dextrose agar medium. Experiments were done in triplicates and antimicrobial activity was expressed as the average inhibition zone diameter produced by the fungal extract.

\section{Cytotoxicity assay}

The cytotoxicity of the crude extract was evaluated against human cancer cell lines such as HeLa, MCF-7 and MG63. The cell lines were obtained from National Centre for Cell Science (NCCS), Pune and grown in Eagles Minimum Essential Medium containing 10\% fetal bovine serum (FBS). The cells were maintained at $37{ }^{\circ} \mathrm{C}, 5 \% \mathrm{CO}_{2}, 95 \%$ air and $100 \%$ relative humidity. Cytotoxicity was assessed using the 3-[4,5-dimethylthiazol-2-yl]2,5-diphenyltetrazolium bromide (MTT) assay. Briefly, hundred microlitres of $1 \times 10^{4}$ cells were seeded in each well of 96 well plate, and allowed to grow for 24-h at $37^{\circ} \mathrm{C}$ and $5 \% \mathrm{CO}_{2}$ conditions. After 24-h of incubation, the cells were treated with serial concentration of crude extract $(18.75 \mu \mathrm{g}, 37.5 \mu \mathrm{g}, 75 \mu \mathrm{g}, 150 \mu \mathrm{g}, 300 \mu \mathrm{g})$. An equal concentration of DMSO was used as control. After $48 \mathrm{~h}$ of incubation, $15 \mu \mathrm{l}$ of MTT $(5 \mathrm{mg} / \mathrm{ml})$ in phosphate buffered saline (PBS) was added to each well and incubated at $37{ }^{0} \mathrm{C}$ for 4 $\mathrm{h}$. The medium with MTT was then flicked off and the formed formazan crystals were solubilized in $100 \mu \mathrm{l}$ of DMSO and then the absorbance at $570 \mathrm{~nm}$ was measured using micro plate reader. The $\%$ growth inhibition was determined using the following formula and the $\mathrm{IC}_{50}$ was determined using Graphpad Prism software.

$\%$ Growth Inhibition $=100-$ Abs $($ Test $) /$ Abs $($ control $) \times 100$.

\section{GC-MS Analysis}

The fungal extract was subjected to GC-MS analysis to identify the bioactive compound. The sample was analysed in Thermo GC- Trace Ultra Ver. 5.0 (DB 5- MS Capillary Standard Nonpolar Column with diameter $0.25 \mathrm{~mm}$, length $30 \mathrm{~m}$, film thickness $0.25 \mu \mathrm{m}$ ) interfaced with mass detector Thermo MS DSQ II (Ion source Single quad EI+), programmed at temperature $70-260^{\circ} \mathrm{C}$ with a rate of $6^{\circ} \mathrm{C} / \mathrm{min}$. Injector flow rate was $220^{\circ} \mathrm{C}$; carrier gas was ultra pure He, column flow rate $1.0 \mathrm{ml} / \mathrm{min}$., injection mode- spilitless. The compounds produced by CMS 3 were tentatively identified through library comparison with NIST database. Compounds listed were tentatively identified strictly on the basis of their quality match $(50 \%$ or better) with the NIST database compounds.

\section{Results}

\section{Fungal isolation and identification}

In the present study, 28 isolates of fungal endophytes were obtained from the leaves of endemic tree Cinnamomum malabatrum. Of these, 13 isolates were sporulated and grouped into five species, namely, Colletotrichum sp., Aspergillus sp., Alternaria sp., Fusarium sp. and Curvularia sp. Among the isolates, species of Colletotrichum was found to be predominant $(\sim 60 \%)$. Preliminary antimicrobial activity of all the isolates revealed that one of the isolates of Colletotrichum, CMS 3, showed significant activity and went through further analysis. The colony morphology of CMS 3 on PDA medium was dense aerial hyphae, initially white gray and later becoming dark gray. Conidia were hyaline, aseptate and cylindrical with obtuse apices, size of the conidia was 10 to $15 \mu \mathrm{m}$ in length and width $2-3 \mu \mathrm{m}$. Based on the morphological character the species was assigned to Colletotrichum sp. (Fig. 1a-b). 
Precise identification was done by amplifying ITS region using ITS1 and ITS4 primers and the sequence was determined. Sequence similarity search was done with NCBI BLAST resulted in several closely related sequences along with them phylogenic analysis was conducted, which resulted in CMS 3 fell into the group of Colletotrichum gloeosporioides (Fig. 2).

\section{Antimicrobial and Cytotoxic activities}

Biological activities of the crude extract were evaluated using antimicrobial activity and cytotoxicity against three cell lines. Ethyl acetate extract of Colletotrichum. gloeosporioides fermentation broth was tested at various concentration $(50,100,200,300,400 \mu \mathrm{g} / \mathrm{ml})$ against Gram- positive, Gram- negative bacteria and fungi, Candida albicans. At low concentration, crude extract $(50 \mu \mathrm{g} / \mathrm{ml})$ did not show the zone of inhibition against the tested organisms, whereas $100 \mu \mathrm{g}$ of crude extract inhibited the growth of all the test organisms (Table 1). The zone of inhibition was measured and this concentration was considered as the minimum inhibitory concentration (MIC). Maximum inhibition was reported at higher concentration $(400 \mu \mathrm{g} / \mathrm{ml})$ which was more or less equal to the standard antibiotics.

The evaluation of cytotoxicity of Colletotrichum gloeosporioides, CMS 3, extract was performed using three cell lines (HeLa, MCF-7 and MG63), which showed reasonable activity against cell lines (Fig. 3). MCF-7 has more sensitivity to crude extract than HeLa and MG63 cell lines. Over all, the extract did not show significant cell inhibition at lower concentrations (18.75 and $37.5 \mu \mathrm{g} / \mathrm{ml}$ ), moderate inhibition $(>25 \%$ and $38 \%$ ) at $75 \mu \mathrm{g} / \mathrm{ml}$ and $>80 \%$ cell inhibition at $150 \mu \mathrm{g} / \mathrm{ml}$. At high concentration $(300 \mu \mathrm{g} / \mathrm{ml})$ crude extract had showed $100 \%$ cell inhibition. The $\mathrm{IC}_{50}$ values for MCF-7, HeLa and MG63 cell lines were respectively 84.2, 94.2, and $162 \mu \mathrm{g} / \mathrm{ml}$.

\section{GC-MS analysis}

The extract of Colletotrichum gloeosporioides, CMS 3 was analyzed by GC-MS. Twenty three components were detected in the crude extract and six of them were identified by comparison with MS Data of NIST (Table 2). Seventeen compounds remained unidentified because the spectral data could not match with any compound in the database. Among the listed compounds, phenol 3, 5- dimethoxy acetate was the most abundant with the relative area of $11.82 \%$. The other notable compounds are 4'-isopropylidene-bis-(2-cyclohexyl) phenol, N-Didehydrohexacarboxy 1- 2, 4, 5-trimethylpiperazine and 1,2, 4- Triazolium ylide. GC-MS analysis of crude extract of Colletotrichum gloeosporioides, CMS 3 by and large produced phenolic derivatives (Table 2).

\section{Discussion}

Plants growing in biodiversity rich areas may contain novel endophytic microorganism (Strobel 2003) and are the lest-explored organisms for biologically active small molecules (Chowdhary et al. 2012, Radic \& Strukelj 2012). Cinnamomum species are widely used in herbal medicine because of its therapeautic potential. Over the last decades, fungal endophytes have been inventoried from various species of Cinnamomum (Strobel et al. 2001, Ezra et al. 2004, Suwannarach et al. 2010, Wang et al. 2011, Han et al. 2012, Kharwar et al. 2012, Santiago et al.2012, Saxena et al. 2014) to harness its potential. In this study, Colletotrichum isolates were found to be predominant fungal isolate from Cinnamomum malabatrum, in which one of isolates CMS 3 showed significant biological activity. The isolate was identified as Colletotrichum gloeosporioides both by morphological and molecular characterization based on ITS rDNA sequences. Colletotrichum gloeosporioides is found to be the most common endophyte in various host plants in the tropics (Zou et al. 2000, Kumar \& Hyde 2004, Gangadevi \& Muthumary 2008, Wang et al. 2008, Arivudainambi et al. 2011, Suwannarach et al. 2012, Zhang et al. 2012, Senthilkumar et al. 2013).

Colletotrichum gloeosporioides crude extract showed significant antimicrobial activity against Gram -Positive and negative bacteria and fungi (Table 1). This findings corroborated with the early study that reported that Colletotrichum gloeosporioides was the prolific producer of 
plethora of antimicrobial compounds, such as colletotric acid and colletoic acid (Zou et al. 2000), diketopiperazines (Trigos et al. 1997), artemisinin (Wang et al. 2006), phillyrin compounds (Zhang et al. 2012) and piperine (Chithra et al. 2014).

Many plant derived natural products like camptothecin, taxol, vinblastine, vincristine are of immense value to combat malignancies (Srivastava et al. 2005). Many of the cytotoxic compounds reported from plants are also produced by endophytic fungi (Schulz et al. 2002; Strobel et al. 2004; Kharwar et al. 2011, Deshmukh \&Verekar 2014). The cytotoxicity evaluation of Colletotrichum gloeosporioides CMS 3, was moderate (Fig. 3) when compared to the National Institute Criteria for Cytotoxicity $\left(\mathrm{IC}_{50}<20 \mu \mathrm{g} / \mathrm{ml}\right.$ ) for screening of crude extracts. About $80 \%$ of the screened crude extracts of endophytic fungus isolated form Stryphnodindron adstringens showed significant cytotoxicity $\left(\mathrm{IC}_{50}<20 \mu \mathrm{g} / \mathrm{ml}\right.$ ) against MCF-7 cell line (Carvalho et al. 2012). However, extracts of endophytic fungi isolated from Viguiera arenaria and Tithonia diversifolia showed moderate activity $\left(\mathrm{IC}_{50}>20 \mu \mathrm{g} / \mathrm{ml}\right)$ against JURKAT cell line (Guimaraes et al. 2008).

The bioactivity of the extract possibly as a result of innate compounds in the extract including N-Didehydrohexacarboxy 1- 2, 4, 5-tri methyl piperazine and other phenol derivatives, identified following GC-MS fragmentation. Piperazine derivatives have potent biological activities such as antibacterial activity (Graz et al. 1999), cytotoxicity (Wang et al. 2012) and antiviral activity (Wang et al. 2013).

In the recent past, few studies have reported dwindling production of plant secondary metabolites by endophytic fungi in successive culturing (Gurudatt et al. 2010, Kusari \& Spiteller 2010, Kumara et al. 2012, Zhao et al. 2013). It may be due to loss of genes or silencing of genes (Kumara et al. 2014). In our case, we have sub cultured Colletotrichum gloeosporioides CMS 3 more than seven times before conducting the biological activity, so it may be the probable reason for moderate bioactivity. Recently, various methodologies were employed to overcome the silencing of genes and to induce the production of bioactive compounds through epigenetic modulations (Gacek \& Strauss 2012, Chen et al. 2013), microbial co-cultivation (Netzker et al. 2015), addition of polysaccharide elicitors (Simic et al. 2014) and in some cases addition of various carbon sources (methanol and ethanol) in microbial fermentation (Zhao et al. 2013).

Even after successive sub culturing of Colletotrichum gloeosporioides, CMS 3, endophytic fungi showed moderate biological activity, which confirm that CMS 3, have great promise as a sustainable resource of biologically active novel secondary metabolites. We have initiated the fermentation of endophytes with elicitors for the discovery and structural elucidation of bioactive compounds from the endophyte Colletotrichum gloeosporioides, CMS 3.

Table 1 Antimicrobial activity of endophytic fungus Colletotrichum gloeosporioides CMS 3, isolated from endemic tree Cinnamomum malabatrum

\begin{tabular}{|c|c|c|c|c|c|}
\hline \multirow[b]{2}{*}{ Test organisms } & \multicolumn{5}{|c|}{ Diameter of inhibition zone $(\mathrm{mm})$ mean \pm S.D. } \\
\hline & $100 \mu \mathrm{g} / \mathrm{ml}$ & $200 \mu \mathrm{g} / \mathrm{ml}$ & $300 \mu \mathrm{g} / \mathrm{ml}$ & $400 \mu \mathrm{g} / \mathrm{ml}$ & $\begin{array}{c}\text { Standard antibiotic } \\
25 \mu \mathrm{g} / \mathrm{ml}\end{array}$ \\
\hline Staphylococcus aureus & $15.0 \pm 2.0^{\mathrm{a}}$ & $17.0 \pm 1.7^{\mathrm{a}}$ & $17.0 \pm 1.7^{\mathrm{a}}$ & $24.0 \pm 2.0^{\mathrm{a}}$ & $28.3 \pm 0.6^{\mathrm{s}}$ \\
\hline Bacillus subtilis & $14.3 \pm 2.1^{\mathrm{a}}$ & $16.7 \pm 1.5^{\mathrm{a}}$ & $17.3 \pm 3.5^{\mathrm{a}}$ & $24.0 \pm 1.7^{\mathrm{a}}$ & $29.3 \pm 0.6^{\mathrm{s}}$ \\
\hline Streptococcus faecalis & $14.0 \pm 1.0^{\mathrm{a}}$ & $15.3 \pm 0.6^{\mathrm{a}}$ & $15.7 \pm 0.6^{\mathrm{a}}$ & $23.0 \pm 2.6^{\mathrm{a}}$ & $30.0 \pm 0.0^{\mathrm{s}}$ \\
\hline Escherichia coli & $12.3 \pm 2.1^{\mathrm{a}}$ & $15.7 \pm 2.1^{\mathrm{a}}$ & $17.3 \pm 1.5^{\mathrm{a}}$ & $20.7 \pm 1.2^{\mathrm{a}}$ & $29.0 \pm 1.0^{\mathrm{s}}$ \\
\hline Salmonella typhimurium & $14.3 \pm 1.2^{\mathrm{a}}$ & $14.3 \pm 1.2^{\mathrm{a}}$ & $16.3 \pm 1.5^{\mathrm{a}}$ & $22.7 \pm 1.5^{\mathrm{a}}$ & $29.7 \pm 0.6^{\mathrm{s}}$ \\
\hline Shigella boydii & $14.3 \pm 2.1^{\mathrm{a}}$ & $15.7 \pm 1.5^{\mathrm{a}}$ & $16.7 \pm 2.3^{\mathrm{a}}$ & $24.3 \pm 1.2$ & $24.7 \pm 1.5^{\mathrm{s}}$ \\
\hline Candida albicans & $14.0 \pm 1.7^{\mathrm{a}}$ & $15.3 \pm 2.1^{\mathrm{a}}$ & $16.0 \pm 2.6^{\mathrm{a}}$ & $20.3 \pm 0.6^{\mathrm{a}}$ & $27.0 \pm 1.0^{\mathrm{f}}$ \\
\hline
\end{tabular}

Data are mean \pm S.D. of triplicate reading of the inhibition zone diameter.

${ }^{a}$ Significantly different from the control at $P<0.05$ using one way ANOVA

${ }^{\mathrm{s}}$ Standard antibiotic Stretomycin for bacterial pathogens.

${ }^{\mathrm{f}}$ Standard antibiotic fluconazole for fungal pathogens. 
Table 2 GC-MS Analysis of the compounds presents in Ethyl acetate extract of Colletotrichum gloeosporioides CMS 3

\begin{tabular}{|c|c|c|c|c|c|}
\hline $\begin{array}{l}\text { Retention } \\
\text { Time }\end{array}$ & $\begin{array}{l}\text { Relative } \\
\text { area } \\
(\%)\end{array}$ & Compound Name & Quality & $\begin{array}{l}\text { Molecular } \\
\text { weight }\end{array}$ & $\begin{array}{l}\text { Molecular } \\
\text { formula }\end{array}$ \\
\hline 23.37 & 7.09 & $\begin{array}{l}\text { N-Didehydrohexacarboxyl-2,4,5-tri } \\
\text { piperazine }\end{array}$ & 96.17 & 222 & $\mathrm{C}_{13} \mathrm{H}_{22} \mathrm{~N}_{2 \mathrm{O}}$ \\
\hline 27.26 & 1.19 & $\begin{array}{l}\text { 6-(t-Butyl imino)-8-(3'-trifluoromethylphenyl)- } \\
\text { 3,4-dihydro-2H, } \\
\text { b][1,3]thiazine-7-carbonitrile }\end{array}$ & 61.17 & 392 & $\mathrm{C}_{19} \mathrm{H}_{19} \mathrm{~F}_{3} \mathrm{~N}_{4} \mathrm{~S}$ \\
\hline 30.76 & 5.25 & 1,2,4-Triazolium ylide & 79.36 & 244 & $\mathrm{C}_{12} \mathrm{H}_{12} \mathrm{~N}_{4} \mathrm{O}_{2}$ \\
\hline 31.07 & 7.99 & 4,4'-isopropylidene-bis-(2-cyclohexyl phenol) & 57.00 & 392 & $\mathrm{C}_{27} \mathrm{H}_{36} \mathrm{O}_{2}$ \\
\hline 33.69 & 2.27 & $\begin{array}{l}\text { Fluoro bis [3-fluorodimethylsilyl-2,2,4,4,6,6- } \\
\text { hexamethyl-1,3,5-triaza-2,4,6- } \\
\text { trisilacyclohexyl]borane }\end{array}$ & 98.22 & 618 & $\mathrm{C}_{16} \mathrm{H}_{50} \mathrm{BF}_{3} \mathrm{~N}_{6} \mathrm{Si}$ \\
\hline 38.39 & 11.82 & Phenol, 3,5-dimethoxy-acetate & 58.29 & 196 & $\mathrm{C}_{10} \mathrm{H}_{12} \mathrm{O}_{4}$ \\
\hline
\end{tabular}
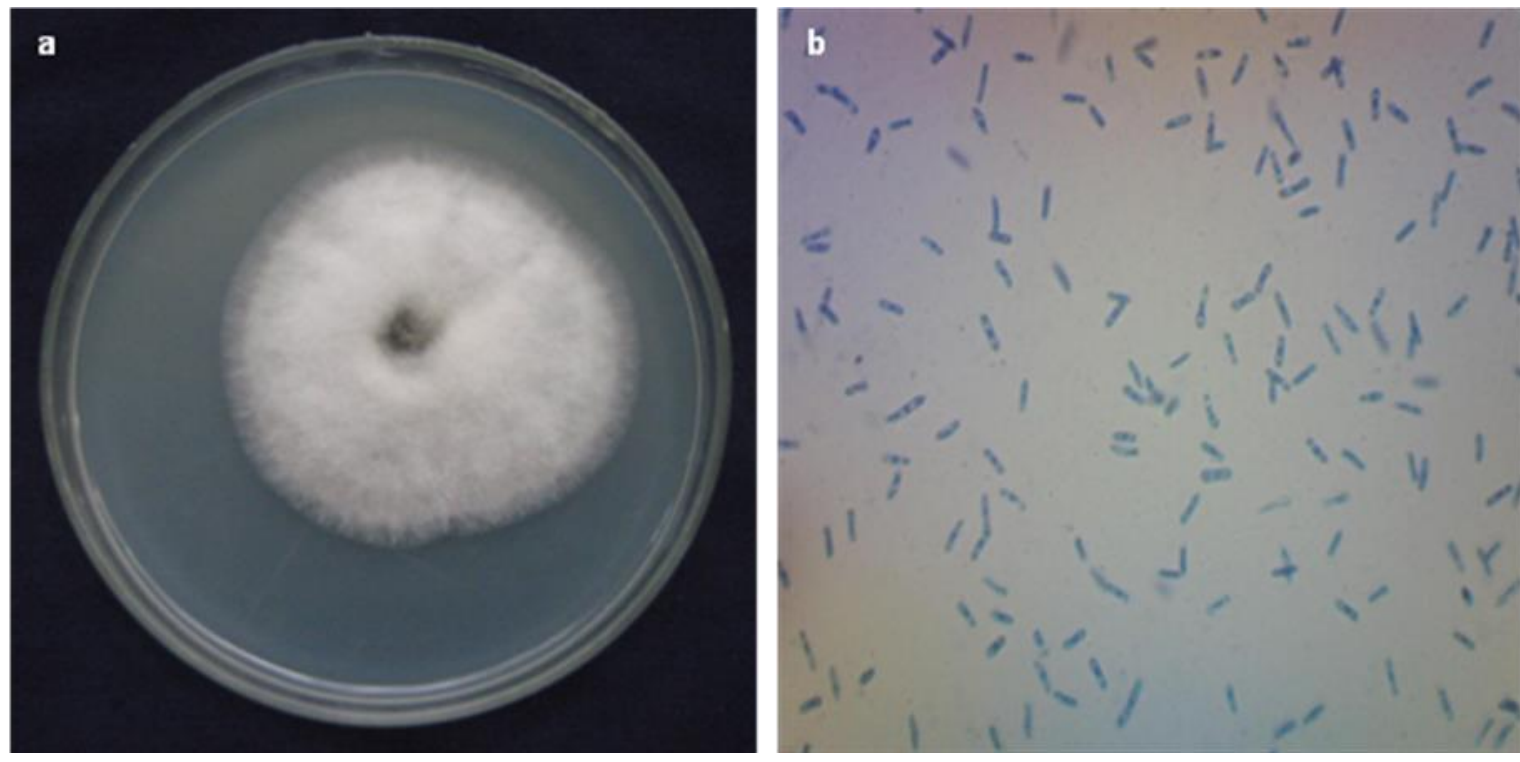

Fig. 1 - Colony morphology and conidia of Colletotrichum isolate, CMS 3 on PDA medium. (a) Colony of CMS 3 after 5 days, (b) Conidia of CMS 3

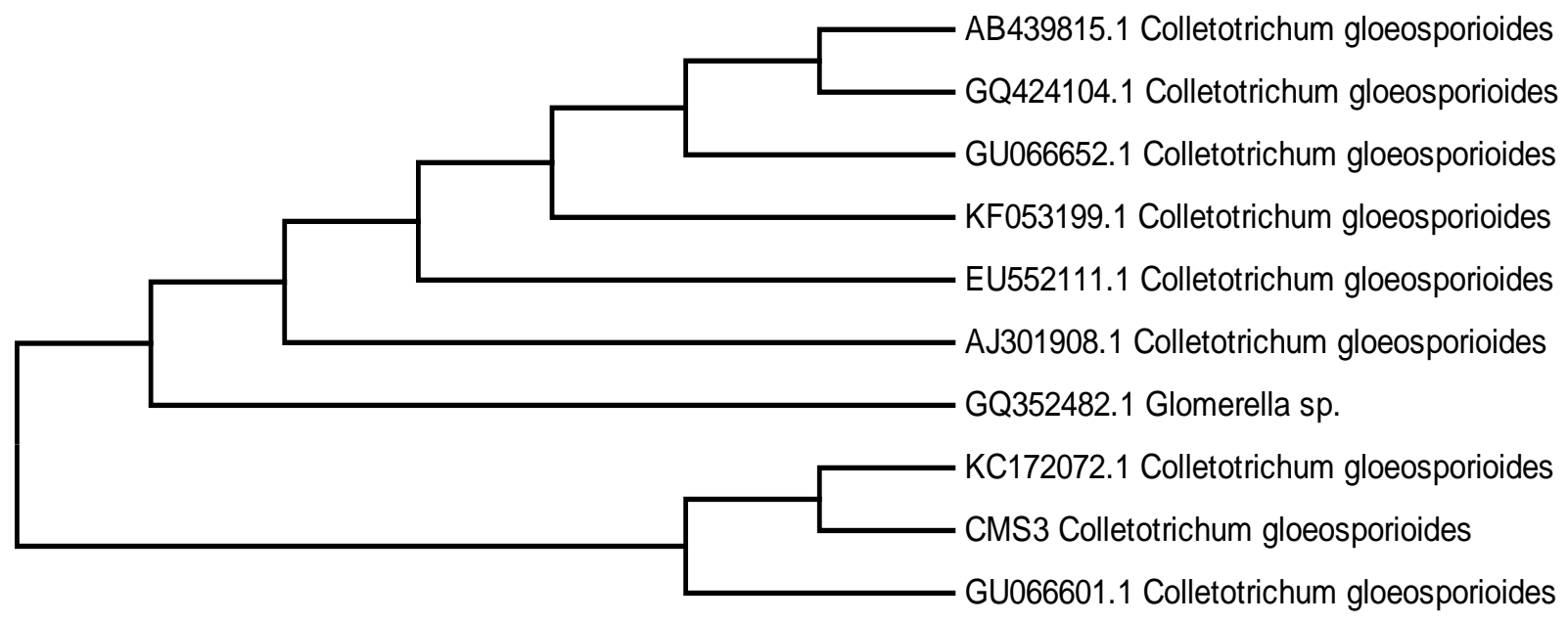

Fig. 2 - Phylogeny NJ tree inferred from ITS rDNA sequences of Colletotrichum gloeosporioides, CMS 3 


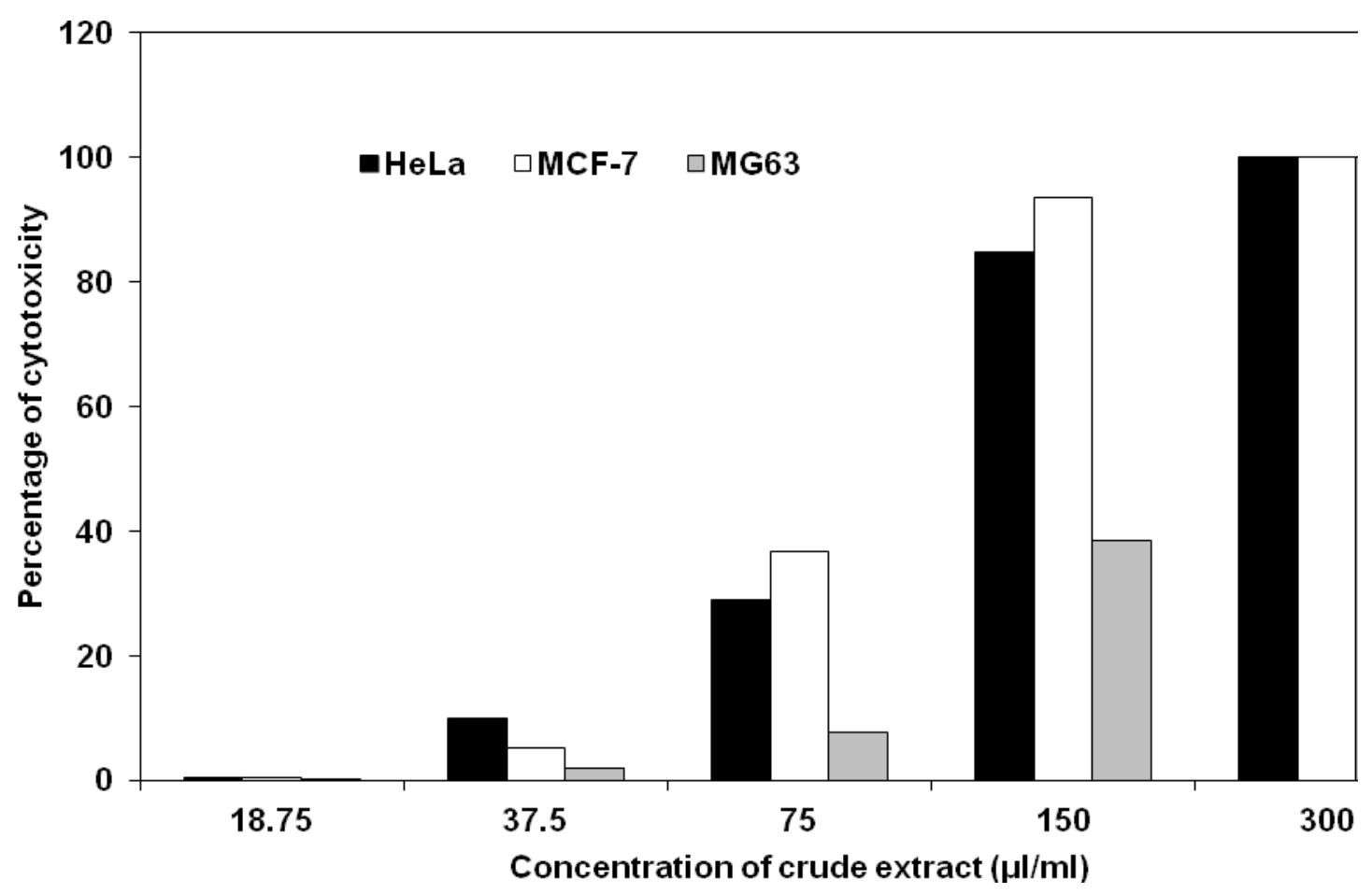

Fig. 3 - In vitro cytotoxic activity of ethylacetate extract of Colletotrichum gloeosporioides against HeLa, MCF-7 and MG63 cancer cell lines

\section{Acknowledgements}

Authors thank to University Grant Commission (UGC, New Delhi) for financial assistance through Major Research Project F. No. 39-409/2010 (SR). We also acknowledge Department of Science and Technology- Fund for Improvement of S\&T infrastructure (DST-FIST) for providing the instrumentation facilities. We extend our gratitude to Department of Collegiate Education (Chennai) for providing Ph.D. fellowship (R.C. No.28122 /K2/2012) to Mr. R. Packiaraj. We would also like to acknowledge Dr. A. Kalidass, Dr. P. Sami and Dr. S. Vivekanandhan for their critical reading of the manuscript and helpful suggestions.

\section{References}

Agarwal SK, Chipa RC, Samantha Suresh KC. 2013 - Anticancer activity of Cinnamomum Malabatrum against Dalton's ascitic lymphoma. International Journal Research in Pharmacology and Pharmacotherapeutics 2, 314-319.

Annegowda HV, Gooi TS, Awang SHH, Alial NA, Mordi MN, Ramanathan S, Mansor SM. 2012 Evaluation of analgesic and antioxidant potency of various extracts of Cinnamomum iners bark. International Journal of Pharmacology 8, 198-203.

Arivudainambi USE, Anand TD, Shanmugaiah V, Karunakaran C, Rajendran A. 2011 - Novel bioactive metabolites producing endophytic fungus Colletotrichum gloeosporioides against multidrug-resistant Staphylococcus aureus. FEMS Immunology and Medical Microbiology $61,340-345$.

Basha NS, Ogbaghebriel A, Yemane K, Zenebe M. 2012 - Isolation and screening of endophytic fungi from Eritrean traditional medicinal plant Terminalia brownii leaves for antimicrobial activity. International Journal of Green Pharmacy 6, 40-44.

Carvalho CR, Goncalves VN, Pereira CB, Johann S, Galliza IV, Alves TMA, Rabello A, Sobral MEG. 2012- The diversity, antimicrobial and anticancer activity of endophytic fungi associated with the medicinal plant Stryphnodendron adstringens (Mart.) Coville (Fabaceae) from the Brazilian savannah. Symbiosis 57, 95-107. 
Chen HJ, Awakawa T, Sun JY, Wakimoto T, Abe I. 2013 - Epigenetic modifier- induced biosynthesis of novel fusaric acid derivatives in endophytic fungi from Datura stramonium L. Natural Products and Bioprospecting 3, 20-23.

Chithra S, Jasim B, Sachidanandan P, Jyothis M, Radhakrishnan EK. 2014 - Piperine production by endophytic fungus Colletotrichum gloeosporioides isolated from Piper nigrum. Phytomedicine 21, 534-540.

Chowdhary K, Kaushik N, Coloma AG, Raimundo CM. 2012 - Endophytic fungi and their metabolites isolated from Indian medicinal plant. Phytochemistry Reviews 11, 467-485.

Deshmukh SK, Verekar SA. 2014 - Fungal endophytes: an amazing and hidden source of cytotoxic compounds. Kharwar et al. (eds) Microbial diversity and Biotechnology in food security, Springer India, DOI 10.1007/978-81-322-1801-2.

Ellis MB. 1971 - Dematiaceous Hyphomycetes. Commonwealth Mycological Institute, Kew, Surrey, England.

Ezra D, Hess WM, Strobel GA. 2004 - New endophytic isolates of Muscodor albus, volatileantibiotic producing fungus. Microbiology 150, 4023- 4031.

Gacek, A, Strauss, J. 2012 - The chromatin code of fungal secondary metabolite gene clusters. Applied Microbiology and Biotechnology 9, 1389-1404.

Gangadevi V, Muthumary J. 2008 - Isolation of Colletotrichum gloeosporioides, a novel endophytic taxol producing fungus from the leaves of a medicinal plant, Justicia gendarussa. Mycologia Balcanica 5, 1-4.

Graz M, Hunt A, Jamie H, Grant G, Milne P. 1999 - Antimicrobial activity of selected cyclic dipeptides. Pharmazie 54, 772-775.

Guimaraes DO, Borges WS, Kawano CY, Ribeiro PH, Goldman GH, Nomizo A, Thiemann OH, Oliva G, Lopes NP, Pupo MT. 2008 - Biological activities from extracts of endophytic fungi isolated from Viguiera arenaria and Tithonia diversifolia. FEMS Immunology and Medical Microbiology 52, 134-144.

Gurudatt PS, Priti V, Shweta S, Ramesha BT, Ravikanth G, Vasudeva R, Amna T, Deepika S, Ganeshaiah KN, Shaanker RU, Puri SC, Qazi NG. 2010 - Attenuation of camptothecin production and negative relation between hyphyal biomass and camptothecin content in endophytic fungal strains isolated from Nothapodytes nimmoniana Graham (Icacinaceae). Current Science 98, 1006-1010.

Han M, Liu T, Cai X, Chen K, Liu C, Brian K, Xue Y, Gu Y. 2012 - A new endophytic Paraconiothyrium brasiliens LT161 shows potential in producing antifungal metabolites against phytopathogens. African Journal of Microbiology Research 6, 7572-7578.

Harikumar B, Basheer S, Haseena. 2010 - Antioxidant potential and antimicrobial activity of Cinnamomum malabathrum (Batka). Oriental Journal of Chemistry 26, 1449- 1453.

Kharwar RN, Maurya AL, Verma VC, Kumar A, Gond SK, Mishra A. 2012 - Diversity and antimicrobial activity of endophytic fungal community isolated from medicinal plant Cinnamomum camphora. National Academy of Sciences India Section B Biological Sciences $82,557-565$.

Kharwar RN, Mishra A, Gond SK, Stierle A, Stierle D. 2011- Antivcancer compounds derived from fungal endophytes: their importance and future challenges. Natural Product Report 28: $1208-1228$.

Kumar DSS, Hyde KD. 2004 - Biodiversity and tissue recurrence of endophytic fungi in Tripterygium wilfordii. Fungal Diversity 17, 69-90.

Kumara PM, Shweta S, Vasanthakumari MM, Sachin N, Manjunatha BL, Jadhav SS, Ravikanth G, Ganeshaiah KN, Shaanker RU. 2014 - Endophytes and Plant Secondary Metabolite Synthesis: Molecular and Evolutionary Perspective. Advances in Endophytic Research. 177190.

Kumara PM, Zuehlke S, Priti V, Ramesha BT, Shweta S, Ravikanth G, Vasudeva R, Santhoshkumar TR, Spiteller M, Shaanker RU. 2012 - Fusarium proliferatum, an endophytic 
fungus from Dysoxylum binectarferum Hook. f, produces rohitukine, a chromane alkaloid possessing anti-cancer activity. Antonie van Leeuwenhoek 101, 323-329.

Kusari S, Singh S, Jayabaskaran C. 2014 - Biotechnological potential of plant-associated endophytic fungi: hope versus hype. Trends in Biotechnology 32, 297-303.

Kusari S, Spiteller M. 2012 - Metabolomics of endophytic fungi producing associated plant secondary metabolites: progress, challenges and opportunities. Roessner U (ed) Metabolomics, InTech, Rijeka, Croatia, 241-266.

Maridass M. 2009 - Hepato protective activity of barks extract of six Cinnamomum species on carbon tetrachloride-induced in albino rats. Folia Medica Indonesiana 45, 177-1890.

Muthumary J. 2013 - Indian Coelomycetes. MJ Publishers, Chennai, India.

Myers N, Mittermeier RA, Mittermeier CG, da Fonsca GAB, Kent J. 2012 - Biodiversity hotspots for conservation priorities. Nature 403, 853-858.

Netzker T, Fischer J, Weber J, Mattern DJ, König CC, Valiante VV, Schroeckh V, Brakhage AA. 2015 - Microbial communication leading to the activation of silent fungal secondary metabolite gene clusters. Frontiers in Microbiology 20, 299.

Radic N, Strukelj B. 2012 - Endophytic fungi: the treasure chest of antibacterial substances. Phytomedicine 19, 1270-1284.

Santiago C, Fitchett C, Munro MH, Jalil J, Santhanam J. 2012 - Cytotoxic and antifungal activities of 5-hydroxyramulosin, a compound produced by an endophytic fungus isolated from Cinnamomum mollisimum. Evidence Based Complementary Alternative Medicine 2012, 1-6.

Saxena S, Meshram V, Kapoor N. 2014 - Muscodor tigerii sp. nov.- volatile antibiotic producing endophytic fungus from the Northern Himalays. Annals of Microbiology.

Schulz B, Boyle C, Draeger S, Rommert AK, Krohn K. 2002 - Endophytic fungi: a source of novel biologically active secondary metabolites. Mycological Research 106: 996- 1004.

Senthilkumar N, Murugesan S, Mohan V, Muthumary J. 2013 - Taxol producing fungal endophyte, Colletotrichum gleosporioides (Penz) from Tectona grandis L. Current Biotica 7, 8-15.

Simic SG, Tusevski O, Maury S, Delaunay A, Joseph C, Hagege H. 2014 - Effects of polysaccharide elicitors on secondary metabolite production and antioxidant response in Hypericum perforatum L. Shoot Cultures. Scientific World Journal 2014.

Srivastva V, Negi AS, Kumar JK, Gupta MM, Khanuja PS. 2005 - Plant based anticancer molecules : a chemical and biological profile of some important leads. Bioorganic \& Medicinal Chemistry 13: 5892-5908.

Strobel GA, Daisy B, Castillo U, Harper J. 2004 - Natural products from endophytic microorganisms. Journal of Natural Products 67, 257-268.

Strobel GA, Dirksie E, Sears J, Markworth C. 2001 - Volatile antimicrobials from Muscodor albus, a novel endophytic fungus. Microbiology 147, 2943-2950.

Strobel GA. 2003 - Endophytes as sources of bioactive products. Microbes Infection 5, 535-544.

Strobel GA. 2002 - Rainforest endophytes and bioactive products. Critical Reviews in Biotechnology 22, 315-333.

Suwannarach N, Bussaban B, Hyde KD, Lumyong S. 2010 - Muscodorcinnamomi, a new endophytic species from Cinnamomum bejolghota. Mycotaxon 114, 15-23.

Suwannarach N, Bussaban B, Nuangmek W, McKenzie EHC, Hyde KD, Lumyong S. 2012 Diversity of endophytic fungi associated with Cinnamomum bejolghota (Lauraceae) in Northern Thailand. Chiang Mai Journal of Science 39, 389-398.

Tamura K, Stecher G, Peterson D, Filipski A, Kumar S. 2013 - MEGA6 : Molecular Evolutionary Genetics Analysis (MEGA) software version 6.0. Molecular Biology and Evolution 30, 27252729.

Tan RX, Zou WX. 2001 - Endophytes: a rich source of functional metabolites. Natural Product Reports 18, 448-459.

Trigos A, Reyna S, Gutierrez M L, Sanchez, M. 1997 - Diketopiperazines from cultures of the fungus Colletotrichum gloesporoides. Natural Product Letters 11, 13-16. 
Wang FZ, Huang Z, Shi XF, Chen YC, Zhang WM, Tian XP, Li J, Zhang S. 2012 - Cytotoxic indole diketopiperazines from the deep sea-derived fungus Acrostalagmus luteoalbus SCSIO F457. Bioorganic \& Medicinal Chemistry Letters 22, 7265-7267.

Wang JW, Zheng LP, Tan RX. 2006 - the preparation of an elicitor from a fungal endophyte to enhance artemisinin production in hairy root cultures of Artemisia annua L. Chinese Journal of Biotechnology 22, 829-834.

Wang P, Xi L, Liu P, Wang Y, Wang W, Huang Y, Zhu W. 2013 - Diketopiperazine derivatives from the marine-derived actinomycete Streptomyces sp. FXJ7.328. Marine Drugs. 11, 10351049.

Wang QX, Li SF, Zhao F, Dai HQ, Bao B, Ding R, Gao H, Zhang LX, Wen HA, Lu HW. 2011 Chemical constituents from endophytic fungus Fusarium oxysporum. Fitoterapia 82, 777781.

Wang YT, Lo HS, Wang PH. 2008 - Endophytic fungi from Taxus mairei in Taiwan: first report of Colletotrichum gloeosporioides as an endophyte of Taxus mairei, Botanical Studies 49, 3943.

World Health Organization. 2008 - the global burden of disease: 2004 uptate. WHO Press, Geneva, Switzerland.

Zhang Q, Wei X, Wang J. 2012 - Phillyrin produced by Colletotrichum gloeosporioides, an endophytic fungus isolated from Forsythia suspensa. Fitoterapia 83, 1500-1505.

Zhao XM, Wang ZQ, Shu SH, Wang WJ, Xu HJ. 2013 - Ethanol and Methanol Can Improve Huperzine A Production from Endophytic Colletotrichum gloeosporioides ES026. PLoS One 8, e61777.

Zou WX, Meng JC, Lu H, Chen GX, Shi GX, Zhang TY. Tan RX. 2000 - Metabolites of Colletotrichum gloeosporioides, an Endophytic Fungus in Artemisia mongolica. Journal of Natural Products 63, 1529-1530. 